\title{
Extension of gray-brown mouse lemur (Microcebus griseorufus) activity period in a disturbed forest in southwestern Madagascar
}

\author{
Krista Fish
}

\author{
Colorado College \\ Department of Anthropology \\ Colorado springs, CO, USA. \\ E-mail: krista.fish@coloradocollege.edu
}

\begin{abstract}
Habitat disturbances may impact behaviors of animals, including their activity patterns. In southwestern Madagascar, timing of gray-brown mouse lemur activities was investigated in adjacent forests with different levels of human disturbance. Mouse lemurs were encountered more frequently during the second part of the night in the unfenced, more disturbed forest than in the fenced, less-disturbed forest. The extension of mouse lemur activity period in the unfenced forest may be due to differences in forest composition resulting in higher travel costs or a loss of canopy cover which may limit their use of torpor.
\end{abstract}

\section{RÉSUMÉ}

Les perturbations de I'habitat peuvent avoir un impact sur le comportement des animaux, y compris sur leur rythme d'activité. Le déroulement des activités des microcèbes a été étudié dans des forêts adjacentes du Sud-ouest de Madagascar. Une de ces forêts a été protégée du pâturage par une clôture tandis que l'autre ne profitait pas d'un tel dispositif en étant ainsi nettement exploitée par l'Homme et son bétail. Les microcèbes ont été rencontrés plus fréquemment au cours de la deuxième partie de la nuit dans la forêt non clôturée que dans la forêt clôturée. Bien que cette étude n'ait pas permis de détecter des différences dans la disponibilité des insectes ou des fruits, des évaluations plus détaillées de la composition des espèces d'arbres et l'abondance des insectes sont nécessaires pour déterminer l'impact de la qualité nutritionnelle ou de la distribution des ressources sur les rythmes d'activité des microcèbes dans la forêt non clôturée. D'un autre côté, I'allongement de la période d'activité des microcèbes dans la forêt non clôturée peut être lié à une perte de la couverture de la canopée, elle-même à l'origine d'une élévation des températures diurnes dans la forêt non clôturée qui réduirait la durée pendant laquelle les microcèbes pourraient être en torpeur dans cette forêt.

\section{INTRODUCTION}

Forest loss, fragmentation, and degradation in Madagascar are threats to its unique biodiversity (Harper et al. 2007). Human activities including hunting of animals, illegal harvesting of plants, and clearing of land for agriculture disturb Malagasy forests (Goodman 2006, Patel 2007, Irwin et al. 2010, Brown et al. 2013). These disturbances degrade forests by altering their structure, affecting resource availability and community composition (Irwin et al. 2010, Brown et al. 2013).

Madagascar's endemic lemurs are tied to forests, yet few studies explore lemur behavioral ecology across disturbance gradients (Irwin et al. 2010). Mouse lemurs (Microcebus spp.) are widespread in a variety of forest types including areas of anthropogenic disturbance (Radespiel 2007, Atsalis 2008). Ranging from 30-110 g in body mass (Atsalis et al. 1996, Rasoloarison et al. 2000, Wrogemann et al. 2001), nocturnal mouse lemurs consume an omnivorous diet (Radespiel 2007, Atsalis 2008). In resource-poor seasons, mouse lemurs may enter a daily or extended period of torpor in which they lower their metabolic rate and reduce energy needs (Schmid 2000, Schmid and Speakman 2000, Kobbe and Dausmann 2009).

Mouse lemurs show an array of responses to different habitat disturbances. In western Madagascar, population densities of gray mouse lemurs (Microcebus murinus) were lower in a secondary forest than in a primary forest (Ganzhorn and Schmid 1998). Gray mouse lemurs in large forest fragments along the east coast were found to have a higher parasite load if they inhabited a more degraded fragment (Raharivololona and Ganzhorn 2009). Mouse lemurs (M. rufus and M. lehilahytsara) from eastern rainforest localities had stable isotope values that suggested a shift toward a more faunivorous diet in fragments and degraded habitats (Crowley et al. 2013) and gray-brown mouse lemurs (M. griseorufus) in the southeast reduced gum feeding and increased insect feeding in disturbed forests (Rasoazanabary 2011).

Habitat degradation may also impact the activity pattern of mouse lemurs. Resources may be spaced further apart in degraded habitat, causing mouse lemurs to increase their ranges and activity period to obtain sufficient resources. Alternatively, because mouse lemurs can reduce their energy needs through the use of torpor, they may shorten their activity period. During a 1.5 month study during the dry season at the Beza Mahafaly Special Reserve (BMSR) in southeastern Madagascar, I assessed whether the activity period of gray-brown mouse lemurs (Microcebus griseorufus) varied in two adjacent deciduous forests with differing disturbance levels.

\section{METHODS}

Parcel 1 of BMSR is approximately 80 hectares in size and bordered on one side by the ephemeral Sakamena River (Figure 1). 


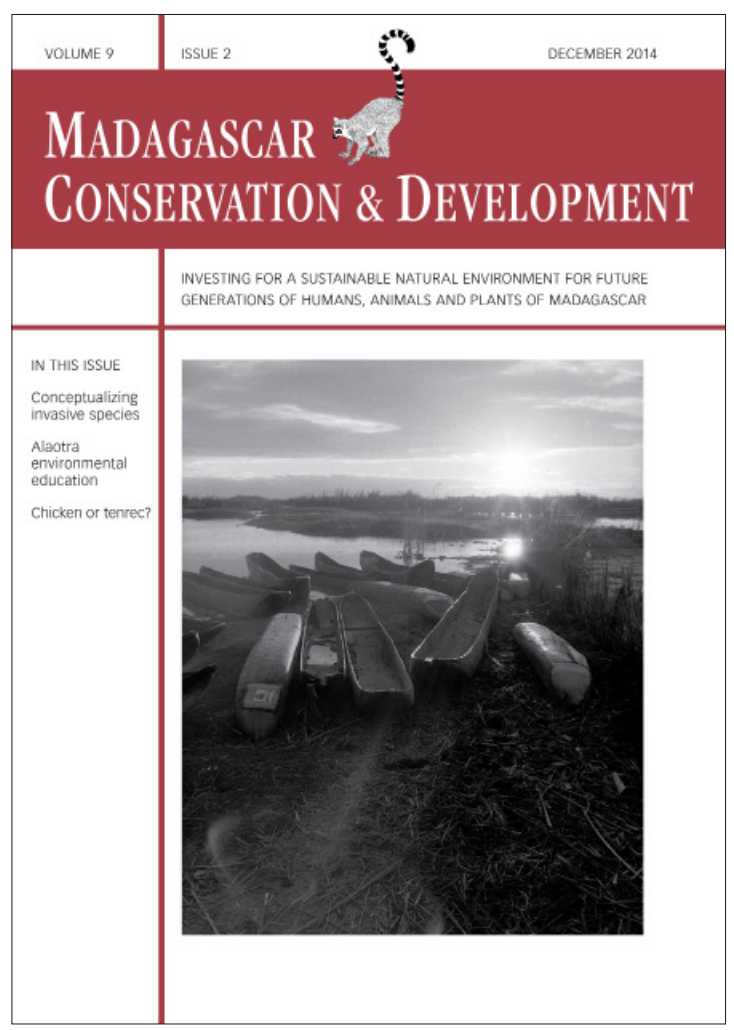

Madagascar Conservation \& Development is the journal of Indian Ocean e-Ink. It is produced under the responsibility of this institution. The views expressed in contributions to MCD are solely those of the authors and not those of the journal editors or the publisher.

All the Issues and articles are freely available at http://www.journalmcd.com

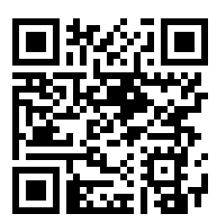

Contact Journal MCD

info@journalmcd.net for general inquiries regarding MCD funding@journalmcd.net to support the journal

Madagascar Conservation \& Development Institute and Museum of Anthropology University of Zurich

Winterthurerstrasse 190

$\mathrm{CH}-8057$ Zurich

Switzerland

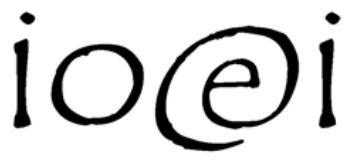

Indian Ocean e-Ink

Promoting African Publishing and Education

www.ioeink.com

Missouri Botanical Garden (MBG)

니는 Missouri Botanical Garden Madagascar Research and Conservation Program BP 3391

Antananarivo, 101, Madagascar 


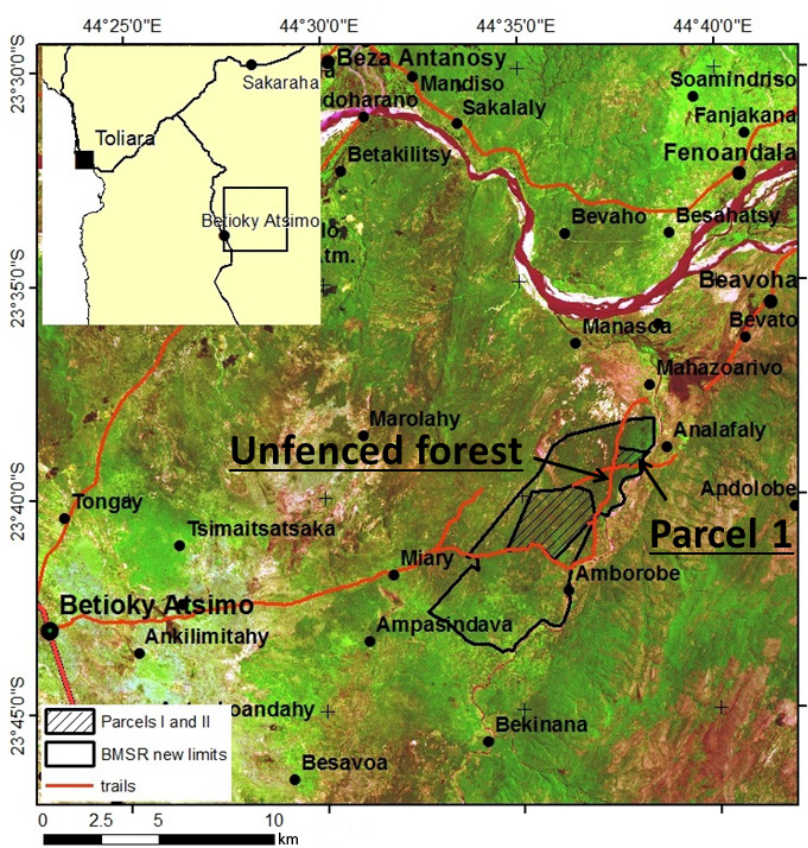

FIGURE 1. Beza Mahafaly Special Reserve with locations of Parcel 1 and the unfenced forests highlighted. Map modified from < http://bezamahafaly. commons.yale.edu/en/maps-and-direction/>

Because of its proximity to the river, soils in the eastern side are moister and support a gallery forest (Sussman and Ratsirarson 2006, Axel and Maurer 2011). Moving west from the river the soils become drier and the forest composition transitions to dry deciduous forest (ibid). This parcel is relatively undisturbed as it is protected from grazing animals by a perimeter fence (Sussman and Ratsirarson 2006). Grazing animals occasionally enter Parcel 1 when fences are down (pers. observ.) or they are hidden in the reserve by local villagers to protect the animals from thieves (Youssouf and Rasoazanabary 2008). Minor disturbances come from a $100 \mathrm{~m} \times 100 \mathrm{~m}$ grid of footpaths created for researchers and also used by local villagers for travel. Local villagers also enter the reserve for occasional collection of fruits (Rasoazanabary 2011).

The neighboring forest (approximately 850 hectares) is located between Parcel 1 and Parcel 2 (Axel and Maurer 2011). Separated from Parcel 1 by the intersection of two dirt roads, this dry deciduous forest is similar to the adjacent western edge of Parcel 1 (ibid). The boundaries of BMSR were recently extended to include this forest; however no perimeter fence protects it. Grazing by goats and cattle in this forest is common and trees have been cut down so that browsing animals can feed on their leaves. Numerous oxcart trails, footpaths, and corral clearings are found in this forest. Because the protected Parcel 1 and this unfenced forest are only separated by the road intersection, variables such as local weather conditions and noise disturbances from the roads are similar.

Between 1 June and 10 July 2011, a six-person research team examined forest structure, food availability, and mouse lemur behaviors in Parcel 1 and the unfenced forest. To compare forest structure between the two forests, we established three transects approximately $1 \mathrm{~km}$ in length in the unfenced forest. Transects paralleled each other, running due west from the road, with 200 m between each transect. In Parcel 1, I selected three established trails from the existing gridded trail system. As with the transects constructed in the unfenced forest, the selected trails were approximately $1 \mathrm{~km}$ in length running east-west from the river, parallel, and separated by $200 \mathrm{~m}$. I selected trees along transects in the unfenced forest and established trails in Parcel 1 every $50 \mathrm{~m}$ and recorded their dbh (diameter at breast height) and height.

Weekly sampling of food abundance took place during the last four weeks of the study. Sampled trees along transects and trails were marked with flagging tape and examined for the presence or absence of fruits, flowers, immature or mature leaves. In order to compare insect abundance, sweep net sampling using a $33 \mathrm{~cm}$ diameter net was conducted at three $10 \mathrm{~m} \times 10 \mathrm{~m}$ plots along trails and transects in both forests. Beat traps were also set under trees within these plots. Total number of insect captures was tallied for each forest.

The research team conducted 246 hours of walks in Parcel 1 and the unfenced forest to locate mouse lemurs. Walks were evenly distributed throughout the night, with half of the walks occurring between 1800 and 2400 and the other half between 2400 and 0600. At a pace of approximately $2 \mathrm{~km}$ per hour, researchers traveled on trails, transects, clearings, and animal paths while using their headlamps to scan the forests for mouse lemurs. When mouse lemurs were located, we recorded the time and their behaviors using continuous focal sampling until they went out of sight.

I examined variation in forest structure and resource availability between the two forests using a proportions t-test. A chi-square test was used to determine: i) if the total number of insects captured in each habitat differed and ii) if differences existed in the number of encounters with mouse lemurs between Parcel 1 and unfenced forest throughout the night. I used only the time and behavior of a mouse lemur upon initial encounter to avoid oversampling the behaviors of well-habituated mouse lemurs. The level of significance for all analyses was set at $p<0.05$.

\section{RESULTS}

The trees in the unfenced habitat were smaller and shorter on average than trees in Parcel 1 in terms of $\mathrm{dbh}$ (Parcel 1 mean $=$ $17.5 \mathrm{~cm}, \mathrm{n}=70, \mathrm{SD}=23.3 \mathrm{~cm}$; Unfencedmean $=12.6 \mathrm{~cm}, \mathrm{n}=66$, $\mathrm{SD}=16.3 \mathrm{~cm}$ ) and tree height (Parcel 1 mean $=8.1 \mathrm{~m}, \mathrm{n}=70, \mathrm{SD}=$ $5.5 \mathrm{~m}$; Unfencedmean $=5.0 \mathrm{~m}, \mathrm{n}=66, \mathrm{SD}=2.2 \mathrm{~m}$ ), but these differences were not significant. Although the presence of mature and immature leaves declined in both forests during this study, a higher percentage of trees in Parcel 1 contained both mature and immature leaves in comparison to the unfenced habitat during three of the four weeks of surveys (week 1: t-1 $=-3.104$, $\mathrm{df}=95, \mathrm{p}=0.001$; week 2 : $\mathrm{t}-1=-1.588, \mathrm{df}=77.8, \mathrm{p}=0.059$; week 3: $\mathrm{t}-1=-1.735, \mathrm{df}=92.6, \mathrm{p}=0.043$; week $4: \mathrm{t}-1=-1.674$, $\mathrm{df}=107.7, \mathrm{p}=0.048)$. The total number of insects captured in both habitats was low (Parcel $1 \mathrm{n}=20$; Unfenced $_{n}=15$ ) and did not differ significantly between habitats (chi-square $=0.7, \mathrm{df}=$ $1, p=0.4$ ). Abundance of trees producing fruits or flowers in both forests was low $(n<3)$ during each week of sampling for each forest and precluded statistical testing.

The frequency of mouse lemur encounters in both forests was similar before midnight when they were encountered 206 times in Parcel 1 and 193 times in the unfenced forest (chi-square $=0.424, d f=1, p=0.515$ ). Upon initial encounter, mouse lemurs in Parcel 1 traveled most frequently (49\% of initial encounters), followed by resting ( $28 \%$ of initial encounters), 
foraging ( $21 \%$ of initial encounters), and other ( $2 \%$ of initial encounters). Those in the unfenced habitat also traveled most frequently (43\% of initial encounters), followed by resting (39\% of initial encounters), foraging ( $15 \%$ if initial encounters), and other ( $3 \%$ of initial encounters).

After midnight, mouse lemurs in the unfenced habitat were encountered more frequently $(n=210)$ than mouse lemurs in Parcel 1 ( $n=137$ ) (chi-square $=15.357, d f=1, p=0.001)$. After midnight, mouse lemurs in Parcel 1 traveled in $43 \%$ of initial encounters, rested in $39 \%$, foraged in $17 \%$, and engaged in other behaviors in $1 \%$. Mouse lemurs in the unfenced forest traveled in $44 \%$ of initial encounters, rested in $32 \%$, foraged in $23 \%$, and engaged in other behaviors in $1 \%$.

\section{DISCUSSION}

In both forests, mouse lemurs were encountered at similar frequencies before midnight. This suggests that a similar number of individuals are roused from torpor to commence traveling and foraging in both forests. After midnight, mouse lemurs in the unfenced habitat were encountered more frequently. Mouse lemurs in the unfenced forest may have been more visible to our research team, however, similar encounter frequencies in both forests before midnight argue against this sample bias. The lower encounter frequency with mouse lemurs in Parcel 1 suggests that many individuals retreat to sleeping nests after midnight while those in the unfenced habitat continue their activity period. This study builds on the work of Rasoazanabary (2011) who documented a higher percentage of active nights for mouse lemurs in another disturbed forest (Ihazoara) near BMSR. An extension of the activity period for mouse lemurs in disturbed forests may contribute to the activity increase observed by Rasoazanabary.

Mouse lemurs in Parcel 1 may be more efficient at foraging, allowing them to retreat to nests earlier in the night. There may be greater food availability in Parcel 1 or lower travel costs due to differences in forest structure between Parcel 1 and the unfenced forest. The similar percentages of time spent traveling by mouse lemurs in both forests argues against differences in travel costs, but more extensive follows of mouse lemurs in each forest are necessary to fully evaluate this. My limited dataset suggest low levels of insects, fruits, and flowers in both forests during this dry season study. However, more extensive phenological monitoring and assessments of plant species composition in the forests, including abundance of trees utilized for gums, are needed. Lower nutritional quality based on differences in tree species composition in each forest may underlie the extension of activity period.

Additionally, higher levels of leaf availability may explain the activity pattern of mouse lemurs in the unfenced habitat. The greater leaf availability in Parcel 1 suggests that more of this forest is shaded throughout the day. Because of a reduction in leaf availability, mouse lemur tree holes in the unfenced forest are likely exposed to more solar radiation during the time of the year when trees have their lowest insulative capacities (Schmid 1998). As a result, tree holes in the unfenced forest may exceed the temperature threshold above which mouse lemurs terminate torpor (Schmid 1998) at earlier times in the day. Because torpor results in energetic savings due to reduced metabolic activity (Schmid and Speakman 2000, Kobbe and Dausmann 2009), mouse lemurs in Parcel 1 may remain in energy-saving torpor longer while those in the unfenced forest are roused from torpor and return to a more active metabolic state earlier in the day. Thus, energy costs may be higher for mouse lemurs in the unfenced habitat, forcing them to remain active longer. Further information regarding daytime temperatures in tree holes in both unfenced and Parcel 1 habitats at BMSR as well as assessments of mouse lemur body temperatures and timing of arousal from torpor in these habitats are needed to test this hypothesis.

\section{ACKNOWLEDGEMENTS}

I would like to thank the staff of MICET (Madagascar Institut pour la Conservation des Ecosystèmes Tropicaux) for their assistance in the acquisition of research visas and permits. The research was funded by a Colorado College Social Sciences Executive Committee Grant and Colorado College Venture Funds. I am indebted to the entire staff at the Beza Mahafaly Special Reserve. Research assistants at Beza Mahafaly who made the research possible include R. Anjarasoaniana, K. Breslin, L. Broudy, J. Sodowsky and S. Soffer. Dr. J. Youssouf facilitated the research at Beza Mahafaly while Drs. M. Sauther and F. Cuozzo provided guidance and logistical support. Finally, this manuscript was greatly improved by the comments of three anonymous reviewers.

\section{REFERENCES}

Axel, A. C. and Maurer, B. A. 2011. Lemurs in a complex landscape: mapping species density in subtropical dry forests of southwestern Madagascar using data at multiple levels. American Journal of Primatolology 73: 38-52. (doi:10.1002/ajp.20872)

Atsalis, S. 2008. A Natural History of the Brown Mouse Lemur. PearsonPrentice Hall, Upper Saddle River, NJ.

Atsalis, S., Schmid, J. and Kappeler, P. M. 1996. Metrical comparisons of three species of mouse lemurs. Journal of Human Evolution 31, 1 61-68. (doi:10.1006/jhev.1996.0049)

Brown, K. A., Johnson, S. E., Parks, K. E., Holmes, S. M., Ivoandry, T., et al. 2013. Use of provisioning ecosystem services drives loss of functional traits across land use intensification gradients in tropical forests in Madagascar. Biological Conservation 161: 118-127. (doi:10.1016/j. biocon.2013.03.014)

Crowley, B. E, Blanco, M. B., Arrigo-Nelson, S. J. and Irwin, M. T. 2013. Stable isotopes document resource partitioning and effects of forest disturbance on sympatric cheirogaleid lemurs. Naturwissenschaften 100, 10: 943-956. (doi:10.1007/s00114-013-1094-6)

Ganzhorn, J. U. and Schmid, J. 1998. Different population dynamics of Microcebus murinus in primary and secondary deciduous dry forests of Madgascar. International Journal of Primatology 19, 5: 785-796. (doi:10.1023/A:1020337211827)

Goodman, S. M. 2006. Hunting of Microchiroptera in south-western Madagascar. Oryx 40, 2: 225-228. (doi:10.1017/S0030605306000354)

Harper, G. J, Steininger, M. K., Tucker, C. J., Juhn, D. and Hawkins, F. 2007. Fifty years of deforestation and forest fragmentation in Madagascar. Environmental Conservation 34, 4: 325-333. (doi:10.1017/ S0376892907004262)

Irwin, M. T., Wright, P. C., Birkinshaw, C., Fisher, B. L., Gardner, C. J., et al. 2010. Patterns of species change in anthropogenically disturbed forests of Madagascar. Biological Conservation 143, 10: 2351-2362. (doi:10.1016/j.biocon.2010.01.023)

Kobbe, S. and Dausmann, K. H. 2009. Hibernation in Malagasy mouse lemurs as a strategy to counter environmental challenge. Naturwissenschaften 96, 10:1221-1227.

Patel, E. R. 2007. Logging of rare rosewood and palisandre (Dalbergia spp.) within Marojejy National Park, Madagascar. Madagascar Conservation \& Development 2, 1: 11-16. (doi:10.4314/mcd.v2i1.44124)

Radespiel, U. 2007. Ecological diversity and seasonal adaptations of mouse lemurs (Microcebus spp.). In: Lemurs: Ecology and Adaptation. L. Gould and M. L. Sauther (eds.), pp 211-234. Springer US. 
Raharivololona, B. M. and Ganzhorn, J. U. 2009. Gastrointestinal parasite infection of the gray mouse lemur (Microcebus murinus) in the littoral forest of Mandena, Madagascar: effects of forest fragmentation and degradation. Madagascar Conservation \& Development 4, 2: 103-112. (doi:10.4314/mcd.v4i2.48650)

Rasoloarison, R. M., Goodman, S. M. and Ganzhorn, J. U. 2000. Taxonomic revision of mouse lemurs (Microcebus) in the western portions of Madagascar. International Journal of Primatology 21, 6: 963-1019. (doi:10.1023/A:1005511129475)

Rasoazanabary, E. 2011. The human factor in mouse lemur (Microcebus griseorufus) conservation: local resource utilization and habitat disturbance at Beza Mahafaly, SW Madagascar. Unpubl. Ph. D. thesis, University of Massachusetts, Amherst. (http://search.proquest.com/ docview/860140823)

Schmid, J. 1998. Tree holes used for resting by gray mouse lemurs (Microcebus murinus) in Madagascar: insulation capacities and energetic consequences. International Journal of Primatolology 19, 5: 797-809. (doi:10.1023/A:1020389228665)

Schmid, J. 2000. Daily torpor in the gray mouse lemur (Microcebus murinus) in Madagascar: energetic consequences and biological significance. Oecologia 123, 2: 175-183. (doi:10.1007/s004420051003)

Schmid, J. and Speakman, J. R. 2000. Daily energy expenditure of the grey mouse lemur (Microcebus murinus): a small primate that uses torpor Journal of Comparative Physiology B 170, 8: 633-641. (doi:10.1007/ s003600000146)

Sussman, R. W., and Ratsirarson, J. 2006. Beza Mahafaly Special Reserve: a research site in southwestern Madagascar. In: Ringtailed Lemur Biology: Lemur catta in Madagascar. A. Jolly, R. W. Sussman, N. Koyama and $\mathrm{H}$. Rasamimanana (eds.), pp 43-51. Springer US.

Wrogemann, D., Radespiel, U. and Zimmerman, E. 2001. Comparison of reproductive characteristics and changes in body weight between captive populations of rufous and grey mouse lemurs. International Journal of Primatology 22, 1: 91-108. (doi:10.1023/A:1026418132281)

Youssouf, J. I. A. and Rasoazanabary, E. 2008. Discovery of Macrotarsomys bastardi at Beza Mahafaly Special Reserve, southwest Madagascar, with observations on the dynamics of small mammal interactions. Madagascar Conservation \& Development 3, 1: 31-37. (doi:10.4314/ mcd.v3i1.44133) 